\title{
ANALISIS KESESUAIAN LAHAN SEMBILAN JENIS TANAMAN UNTUK AGROFORESTRI DI NAMBO, JAWA BARAT
}

\author{
Land Suitability Assessment of Nine Species for Agroforestry in Nambo, West Java
}

\section{Tigor Butarbutar $^{1 *}$, Ismatul Hakim², Niken Sakuntaladewi², Hariatno Dwiprabowo², Lukas Rumboko ${ }^{2}$ dan/and Setiasih Irawanti ${ }^{2}$}

\author{
${ }^{1}$ Pusat Penelitian dan Pengembangan Hutan \\ Jalan Gunung Batu No.5 Bogor, Jawa Barat, Indonesia.Telp. 0251-8633234.Fax.0251-8638111 \\ ${ }^{2}$ Pusat Penelitian dan Pengembangan Sosial, Ekonomi, Kebijkan dan Perubahan Iklim \\ Jalan Gunung Batu No.5 Bogor, Jawa Barat, Indonesia 16618.Telp.0251-8633944.Fax.0251-8634924 \\ "Email: tigtars@yahoo.co.id
}

Tanggal diterima: 26 April 2017; Tanggal direvisi: 11 Desember 2017; Tanggal disetujui: 18 April 2018

\begin{abstract}
One of the weakness of agroforestry practices in West Java was that the pattern of species mixing was not based on site characteristics such as soil, climate, and topography and caused low production. This research was conducted to ascertain the land suitability classes for nine species, which are: Tectona grandis,

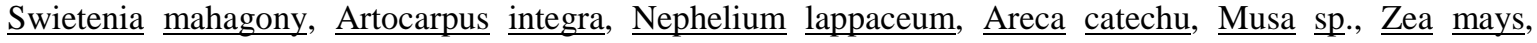
$\underline{\text { Capsicum }} \underline{\mathrm{sp}}$. and Pennisetum purpureum, along with their optimum combination. The research was located in two sites (Acacia mangium) and community mixed plantation in Nambo village, Klapanunggal subdistrict, Bogor regency, West Java using the "Minimum Limiting Factor" method. The results showed that the land suitability class in $\underline{\mathrm{A}}$. mangium site and mixed plantation site for species of: $\underline{\mathrm{T}}$. grandis, $\underline{\mathrm{S}}$. mahagoni, N. lappaceum, A. catechu, Musa sp., Z. mays, Capsicum sp., and $\underline{\mathrm{P}}$. purpureum belong to marginal suitable; where as $\underline{\mathrm{A}}$ integra belongs to not suitable $(N)$. The best combination in both sites consist of one tree species with one Multi Purpose Tree species and one food crop or $\underline{\mathrm{P}}$. purpureum.
\end{abstract}

Keywords: Rainfall and marginal, site, slope, suitability

\begin{abstract}
ABSTRAK
Salah satu kelemahan praktik agroforestri di Jawa Barat adalah pemilihan dan pencampuran jenis belum didasarkan pada karakteristik tapak seperti tanah, iklim dan topografi yang menyebabkan produksi rendah. Penelitian ini bertujuan untuk mengetahui kesesuaian lahan sembilan jenis tanaman yaitu jati (Tectona grandis), mahoni (Swietenia mahagoni), nangka (Artocarpus integra), rambutan (Nephelium lappaceum), pinang (Areca catechu), pisang (Musa sp.), jagung (Zea mays), cabe (Capsicum sp.) dan rumput gajah (Pennisetum purpureum) serta kombinasi jenis yang optimal. Penelitian dilakukan pada dua tapak (Acacia mangium dan tanaman campuran) hutan kemasyarakatan di Desa Nambo, Kecamatan Klapanunggal Kabupaten Bogor,Jawa Barat, dengan metode faktor pembatas minimum. Hasil penelitian menunjukkan bahwa kelas kesesuaian lahan pada tapak A. mangium dan tanaman campuran untuk jati, mahoni, rambutan, pinang pisang, jagung, cabe dan rumput gajah termasuk ke dalam kategori sesuai marginal sedangkan nangka termasuk ke dalam kategori tidak sesuai. Kombinasi jenis yang paling memungkinkan adalah campuran 1 jenis tanaman kayu, 1 jenis tanaman serbaguna dan 1 jenis tanaman pangan atau rumput gajah.
\end{abstract}

Kata kunci: Curah hujan dan marginal, kesesuaian, lereng, tapak

\section{PENDAHULUAN}

Pengembangan agroforestri di berbagai wilayah yang tidak didasarkan pada analisis kesesuaian lahan akan menyebabkan produksi yang tidak optimum, demikian pula sebaliknya (Butarbutar, 2015; Rahim, Hasnain, \& Shamsi, 2010). Oleh 
sebab itu, optimalisasi produktivitas agroforestri di berbagai wilayah telah dilakukan melalui pemilihan jenis pohon, antara lain tanaman berkayu, tanaman serbaguna atau Multy Purpose Tree Species (MPTs), tanaman perkebunan, tanaman pertanian (pangan), dan tanaman pakan ternak berdasarkan analisis kesesuaian lahan (Asmarhansyah Badayos, Sanchez, Cruz, \& Florece, 2017; Butarbutar, 2015; Wang, Zhong, Gao, Xi, \& Zhang, 2015; dan Wicaksono, Putra, \& Muhartini, 2015). Penilaian kesesuaian lahan untuk pengembangan agroforestri ditunjukkan untuk mengetahui kesediaan zat hara, keadaan topografi, altitude dan karakteristik lahan lainnya di lokasilokasi yang dikembangkan (Ahmad, \& Goparaju, 2017).

Kawasan hutan di sekitar Desa Nambo, Kecamatan Klapanunggal, Kabupaten Bogor, Jawa Barat, merupakan areal Perum Perhutani Jawa Barat yang termasuk tidak produktif (bonita rendah untuk kelas perusahaan Pinus merkusii Jungh et de Vriese). Pada saat penelitian dilakukan, peruntukan lahan ditunjukkan untuk pengembangan hutan kemasyarakatan berupa areal agroforestri, areal persawahan, hutan tanaman Acacia mangium Wild. dan belukar. Pertumbuhan tanaman agroforestri yang ada seperti sengon dan nangka belum terlihat maksimal, sehingga peningkatan produktivitas lahannya perlu diawali dengan penilaian kesesuaian lahan untuk berbagai jenis tanaman yang diinginkan.

Penelitian ini bertujuan mengetahui kesesuaian lahan untuk sembilan jenis tanaman penghasil kayu, tanaman serbaguna, tanaman pangan dan tanaman pakan ternak, yaitu jati (Tectona grandis L.), mahoni daun besar (Swietenia macrophylla King.), nangka (Artocarpus integra Merr.), rambutan (Nephelium lappaceum L.), pinang (Areca catechu L.), pisang (Musa sp.) dan tanaman palawija seperti jagung (Zea mays L.), cabe (Capsicum sp.), dan rumput gajah
(Pennisetum purpureum Schumach.), serta kombinasi jenis yang optimal.

\section{METODOLOGI}

\section{A. Lokasi Penelitian}

Penelitian dilaksanakan pada tahun 2014 di kawasan Hutan Produksi di Desa Nambo, Kecamatan Klapanunggal, Kabupaten Bogor. Kawasan tersebut termasuk ke dalam Blok Hutan Cibedil, Kelompok Hutan Gunung Karang, RPH Gunung Karang, BKPH Jonggol KPH Bogor. Kondisi iklim di Kecamatan Klapanunggal termasuk tipe A dengan jumlah curah hujan per tahun sebesar 3.500$4.000 \mathrm{~mm}(60,06 \%$ luas wilayah $)$, sedangkan curah hujan per tahun di bagian utara sebesar 3.000-3.500 mm $(39,39 \%)$ dan di bagian selatan sebesar 4.000-4.500 mm (0,54\%). Tanah di lokasi penelitian termasuk ke dalam jenis podsolik dan latosol. Vegetasi di dua tapak penelitian masing-masing adalah tapak tanaman A. mangium (AM) umur 7 tahun (tahun tanam 2007) dan tapak tanaman campuran (TC) dengan vegetasi jenis Falcataria molucana (Miq.) Barneby \& Grimes., Leucaena leucocephala (Lam.) de Wit., A. integra dan lain-lain.

\section{B. Metode}

Penelitian dilaksanakan pada dua tapak AM dan TC dengan tahapan:

(1) Deskripsi profil tapak AM dan TC untuk mengetahui kualitas lahan, yaitu kemiringan, batuan permukaan, tumbuhan bawah, drainase, kedalaman perakaran dan lain-lain.

(2) Pengambilan contoh tanah terganggu lapisan atas (A) dan lapisan bawah (B) dari masing-masing tapak di atas.

(3) Analisis rutin tanah dilakukan di Laboratorium Tanah Balai Penelitian Tanah Bogor. 
Tigor Butarbutar, Ismatul Hakim, Niken Sakuntaladewi, Hariatno Dwiprabowo, Lukas Rumboko dan Setiasih Irawanti

\section{Analisis Data}

Penilaian kesesuaian lahan untuk sembilan jenis tanaman (penghasil kayu, MPTs, pangan, dan ternak) dilakukan menggunakan metode Simple Limitation Method atau Faktor Pembatas Sederhana untuk jenis jati (T. grandis), mahoni (S. macrophylla), nangka (A. integra), rambutan (N. lappaceum), pinang (A. catechu), pisang (Musa sp.), dan tanaman palawija seperti jagung (Z. mays), cabe (Capsicum sp.), dan rumput gajah (P. purpureum); (Ritung,Wahyuanto, Agus, \& Hidayat, 2007). Penilaian dilakukan dengan menggunakan empat kelas kesesuaian lahan yang dikategorikan sebagai $S_{1}$ (sesuai), $S_{2}$ (sesuai moderat), $S_{3}$ (sesuai marginal), dan $\mathrm{N}$ (tidak sesuai). Setiap kelas terdiri atas sub-kelas yang berhubungan dengan faktor pembatas. Dengan demikian, setiap kelas berhubungan dengan satu atau lebih faktor pembatas, tetapi faktor dominan diletakkan terlebih dahulu. Faktor dominan adalah faktor pembatas yang paling menyebabkan kelas kesesuaian lahan menjadi kelas terendah. Kemudian, penentuan kombinasi jenis hutan tanaman campuran dilakukan dengan menggabungkan jenis-jenis yang mempunyai kelas kesesuaian yang minimal sama atau di atasnya. Jumlah jenis kombinasi (campuran) dilakukan dengan prinsip 1 jenis tanaman kayu, 1 jenis tanaman MPTs, dan 1 jenis tanaman pangan atau pakan ternak, sehingga jumlah jenis yang dikombinasikan maksimal tiga jenis.

\section{HASIL DAN PEMBAHASAN}

\section{A. Hasil}

Hasil penelitian terdiri dari empat bagian yaitu deskripsi profil tanah, analisis sifat fisik dan kimia tanah dan analisis kesesuaian lahan.

\section{Deskripsi profil tanah}

Hasil deskripsi profil tanah di dua lokasi dengan tebal lapisan A termasuk tipis, tekstur liat berat dengan konsistensi (sangat lengket, sangat plastis dan teguh) dan drainase agak buruk menunjukkan secara fisik areal penelitian termasuk tidak subur dan lahan yang sulit untuk diolah untuk tanaman budidaya. Hasil deskripsi profil tanah di areal penelitian secara detail disajikan pada Tabel 1.

\section{Analisis sifat fisik dan kimia tanah}

Hasil analisis laboratorium sifat fisik kimia tanah $\left(\mathrm{pH} \mathrm{H}_{2} \mathrm{O}, \mathrm{pH} \mathrm{KCl}\right.$, tekstur, bahan organic $\mathrm{C}, \mathrm{N}, \mathrm{C} / \mathrm{N}$; $\mathrm{P}$ tersedia, Ca-tersedia; (Ca, $\mathrm{K}, \mathrm{Mg}$ dan $\mathrm{Na}$ ) tertukar; Total Kation Tukar, Kapasitas Tukar Kation (KTK) dan Kejenuhan Basa (KB) disajikan pada Tabel 2 dan 3.

Tabel 2 menunjukkan keasaman tanah termasuk sangat asam sampai agak masam pada tapak A. mangium dan masam di tapak tanaman campuran. Nilai $\mathrm{pH} \mathrm{KCl}$ yang lebih rendah dari $\mathrm{pH} \mathrm{H}_{2} \mathrm{O}$ menunjukkan masih terdapat keasaman potensial berupa $\mathrm{Al}^{3+}$. Tekstur tanah diseluruh lokasi untuk semua lapisan termasuk lempung berliat dengan persentase liat berkisar 38-58\%. Tekstur lempung berliat termasuk berat jika dikaitkan dengan pengolahan lahan dan pertumbuhan akar tanaman. Kandungan bahan organik yang dicirikan oleh Corganik termasuk sedang di lapisan atas pada ketiga profil dan sangat rendah pada lapisan B profil pada tapak A. mangium dan tapak tanaman campuran. Kandungan C-organik di lapisan atas lokasi belukar termasuk sangat rendah. Kandungan bahan organik yang termasuk sangat rendah sampai rendah ini menunjukkan kehidupan mikroorganisma tanah termasuk rendah yang mengakibatkan proses pembentukan lapisan atas yang subur (lapisan A) menjadi lambat. Kemudian tingkat pelapukan yang dicirikan oleh nilai $\mathrm{C} / \mathrm{N}<10$ (rendah) menunjukkan 
tingkat pelapukan yang relatif baik (standar $\mathrm{C} / \mathrm{N}<12$, termasuk baik). Sifatsifat kimia tanah lainnya dapat dilihat pada Tabel 3.

Berdasarkan Tabel 3, kandungan Ptersedia juga termasuk sangat rendah dan pada lapisan B lokasi Acacia mangium dan lapisan A lokasi campuran tidak terukur atau sangat rendah sekali. Kemudian kandungan Ca-tertukar pada seluruh lapisan termasuk sedang sampai tinggi, demikian juga kandungan $\mathrm{Mg}$ tertukar termasuk sedang sampai tinggi kecuali pada lapisan B di tapak A. mangium. Kandungan K-tertukar termasuk rendah sampai sangat rendah.
Kandungan Na-tertukar untuk seluruh lapisan termasuk sangat rendah. Jumlah kation tertukar tertinggi terdapat pada campuran, diikuti oleh lokasi A. mangium dan terendah di lokasi tanaman campuran. Nilai kejenuhan basa termasuk tinggi sampai sangat tinggi, kecuali di lapisan B lokasi A. mangium rendah dan di lokasi campuran termasuk sedang. Secara umum berdasarkan deskripsi profil di lapangan, hasil analisis sifat fisik dan kimia tanah menunjukkan bahwa kesuburan tanah relatif kurang subur baik di tapak A. mangium maupun tapak tanaman campuran.

Tabel (Table) 1. Deskripsi profil tanah di lokasi penelitian (Soil profile descriptionatresearch area)

\begin{tabular}{|c|c|c|}
\hline $\begin{array}{c}\text { Profil/Deskripsi } \\
\text { (profile/Description) }\end{array}$ & $\begin{array}{c}\text { Tapak }(\text { Site }) \\
\text { Acacia mangium* }\end{array}$ & $\begin{array}{c}\text { Tanaman campuran (Mixed } \\
\text { plantation)/Agroforestri (Agroforestry)* }\end{array}$ \\
\hline $\begin{array}{l}\text { Tebal lapisan } \\
\text { (Layer thickness) A }\end{array}$ & $10-12 \mathrm{~cm}$ & $5-7 \mathrm{~cm}$ \\
\hline $\begin{array}{l}\text { Tebal lapisan } \\
\text { (Layer thickness) B }\end{array}$ & $12-42 \mathrm{~cm}$ & $7-40 \mathrm{~cm}$ \\
\hline $\begin{array}{l}\text { Batas lapisan } \\
\text { (Layer border) }\end{array}$ & $\begin{array}{l}\text { Berombak berangsur (Gradually } \\
\text { wavy) }\end{array}$ & Berombak berangsur (Gradually wavy) \\
\hline $\begin{array}{l}\text { Warna lapisan } \\
\text { (Layer colour) A }\end{array}$ & 7,5 YR 2,5/3 (Very dark brown) & 7,5 YR 3/1 (Very dark grey) \\
\hline $\begin{array}{l}\text { Warna lapisan } \\
\text { (Layer colour)B }\end{array}$ & 7,5 YR 4/4 (Brown) & 7,5 YR 4/6 (Strong brown) \\
\hline $\begin{array}{l}\text { Tekstur lapisan (Layer } \\
\text { texture) A }\end{array}$ & Liat berat (Heavy clay) & Liat berat (Heavy clay) \\
\hline $\begin{array}{l}\text { Tekstur lapisan (Layer } \\
\text { texture) B }\end{array}$ & Liat berat (Heavy clay) & Liat berat (Heavy clay) \\
\hline $\begin{array}{l}\text { Struktur lapisan (Layer } \\
\text { structure) A }\end{array}$ & Gumpal bersudut (Angular blocky) & Gumpal bersudut (Angular blocky) \\
\hline $\begin{array}{l}\text { Struktur lapisan (Layer } \\
\text { structure)B }\end{array}$ & Gumpal bersudut (Angular blocky) & Gumpal bersudut (Angular blocky) \\
\hline $\begin{array}{l}\text { Plastisitas lapisan (Layer } \\
\text { plasticity) A }\end{array}$ & $\begin{array}{l}\text { Sangat lengket (Very sticky), sangat } \\
\text { plastis (very c dan teguh (firm) }\end{array}$ & $\begin{array}{c}\text { Sangat lengket (Very sticky). Plastis } \\
\text { (Elastic), teguh (firm) }\end{array}$ \\
\hline $\begin{array}{l}\text { Plastisitas lapisan (Layer } \\
\text { plasticity)B }\end{array}$ & $\begin{array}{l}\text { Sangat lengket (Very sticky), sangat } \\
\text { plastis (very elastic), teguh (firm) }\end{array}$ & $\begin{array}{c}\text { Sangat lengket (Very sticky), plastis (very } \\
\text { elastic), teguh (firm) }\end{array}$ \\
\hline $\begin{array}{l}\text { Tebal serasah (Litter } \\
\text { thickness) }\end{array}$ & $5 \mathrm{~cm}$ & $2 \mathrm{~cm}$ \\
\hline $\begin{array}{l}\text { Jneis tumbuhan bawah } \\
\text { (Underground species) }\end{array}$ & $\begin{array}{c}\text { Rumput berbagai jenis (Varying } \\
\text { grasses), harimonting } \\
\text { (Rhodomyrtus tomentosa) }\end{array}$ & Rumput berbagai jenis (Varying grasses) \\
\hline $\begin{array}{l}\text { Ketinggian dari permukaan } \\
\text { laut (Altitude) }\end{array}$ & $215 \mathrm{~m}$ & $210 \mathrm{~m}$ \\
\hline $\begin{array}{l}\text { Kemiringan lahan (Land } \\
\text { slope) }\end{array}$ & $50 \%$ & $50 \%$ \\
\hline Tipe liat (Type of clay) & Montmorilonit * & Montmorilonit* \\
\hline Drainase (Drainage) & Agak buruk (Slightly poor) & Agak buruk (Slightly poor) \\
\hline
\end{tabular}

Keterangan (Remarks): * = Tipe liat yang kembang-susut (Swelling-shrinking clay) 


\section{Analisis Kesesuaian Lahan Sembilan Jenis Tanaman untuk Agroforestri Di Nambo, Jawa Barat}

Tigor Butarbutar, Ismatul Hakim, Niken Sakuntaladewi, Hariatno Dwiprabowo, Lukas Rumboko dan Setiasih Irawanti

Tabel (Table) 2. Kelas sifat fisik dan kimia tanahdi areal penelitian (The physical and chemical properties classes in research area)

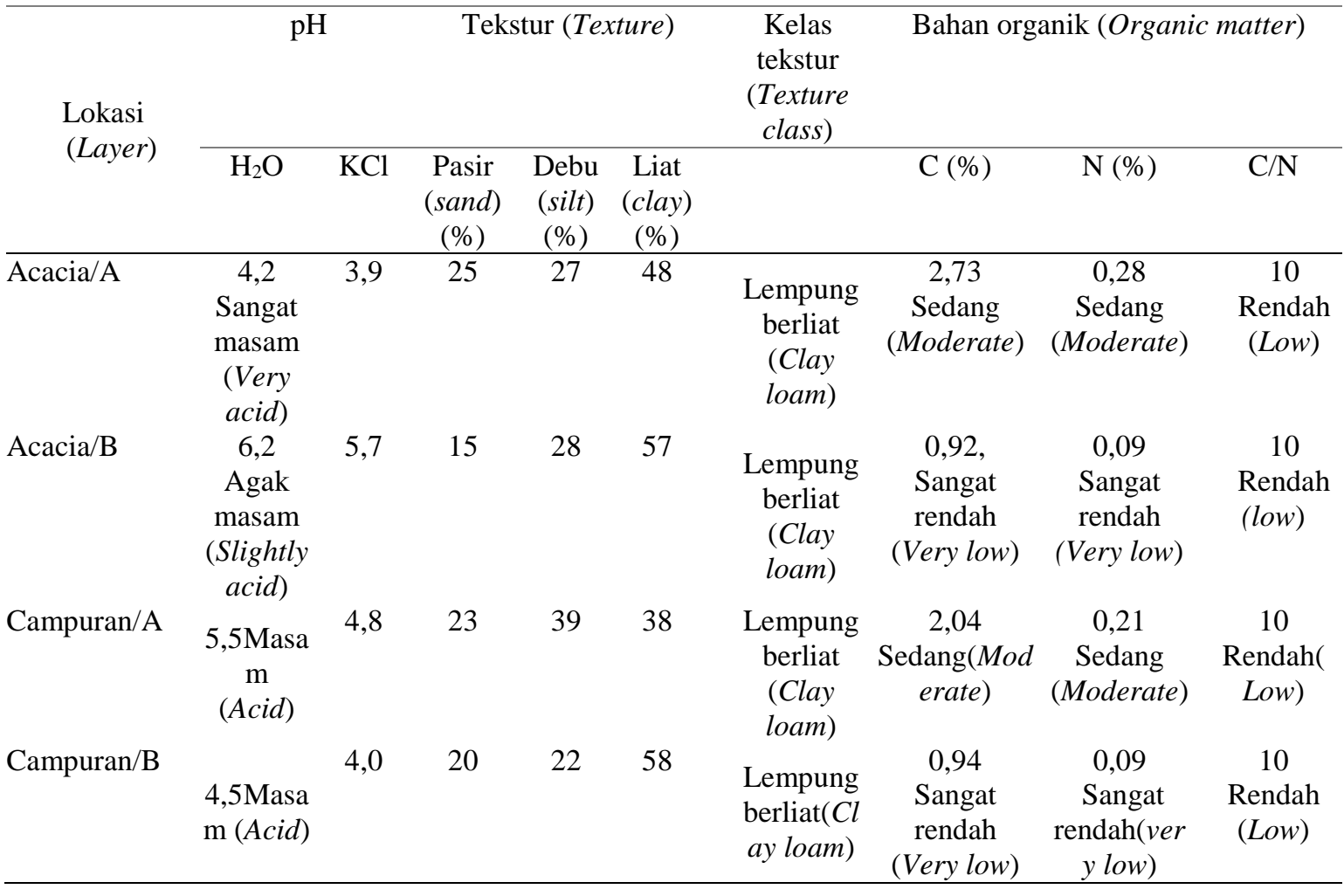

Tabel (Table) 3. Kelas sifat kimia di areal penelitian (The other chemical properties class in research area)

\begin{tabular}{|c|c|c|c|c|c|c|c|c|}
\hline \multirow{2}{*}{$\begin{array}{l}\text { Lokasi/ } \\
\text { lapisan } \\
\text { (Location/ } \\
\text { Layer) }\end{array}$} & \multirow{2}{*}{$\begin{array}{c}\text { P-tersedia } \\
\text { (Available) } \\
\text { (ppm), } \\
\text { Bray 1 }\end{array}$} & \multicolumn{4}{|c|}{$\begin{array}{l}\text { Nilai tukar kation (Cation exchange) } \\
(\mathrm{cmol} / \mathrm{kg})\end{array}$} & \multirow{2}{*}{$\begin{array}{c}\text { Jumlah } \\
\text { (Sum) } \\
\text { (cmol/ kg) }\end{array}$} & \multirow[t]{2}{*}{$\begin{array}{l}\mathrm{KTK} \\
(C E C)\end{array}$} & \multirow[t]{2}{*}{$\begin{array}{l}\mathrm{KB}(B S) \\
\quad(\%)\end{array}$} \\
\hline & & $\mathrm{Ca}$ & $\mathrm{Mg}$ & $\mathrm{K}$ & $\mathrm{Na}$ & & & \\
\hline $\begin{array}{l}\text { A. } \\
\text { mangium/A }\end{array}$ & $\begin{array}{l}2,4 \\
\text { Sangat } \\
\text { rendah } \\
(\text { Very } \\
\text { low) }\end{array}$ & $\begin{array}{c}7,77 \\
\text { Sedang } \\
\text { (Moderate) }\end{array}$ & $\begin{array}{c}1,34 \\
\text { Sedang } \\
\text { (Moderate) }\end{array}$ & $\begin{array}{c}0,08 \\
\text { Sangat } \\
\text { rendah } \\
(\text { Very } \\
\text { low) }\end{array}$ & $\begin{array}{c}0,05 \\
\text { Sangat } \\
\text { rendah } \\
(\text { Very } \\
\text { low) }\end{array}$ & 9,24 & 10,58 & $\begin{array}{l}87 \text { Sangat } \\
\text { tinggi } \\
\text { (Very } \\
\text { high) }\end{array}$ \\
\hline $\begin{array}{l}\text { A.mangium/ } \\
\text { B }\end{array}$ & - & $\begin{array}{c}3,18 \\
\text { Rendah } \\
(\text { Low })\end{array}$ & $\begin{array}{c}0,54 \\
\text { Rendah } \\
(\text { Low })\end{array}$ & $\begin{array}{c}0,05 \\
\text { Sangat } \\
\text { rendah } \\
\text { (Very } \\
\text { low) }\end{array}$ & $\begin{array}{c}0,04 \\
\text { Sangat } \\
\text { rendah } \\
(\text { Very } \\
\text { low) }\end{array}$ & 3,81 & 14,23 & $\begin{array}{c}>100 \\
\text { Sangat } \\
\text { tinggi } \\
(\text { Very } \\
\text { high) }\end{array}$ \\
\hline $\begin{array}{l}\text { Campuran } \\
\text { (Mixed } \\
\text { species)/A }\end{array}$ & - & $\begin{array}{l}19,48 \\
\text { Tinggi } \\
(\text { High })\end{array}$ & $\begin{array}{c}3,53 \\
\text { Tinggi } \\
(\text { High })\end{array}$ & $\begin{array}{c}0,14 \\
\text { Rendah } \\
(\text { Low })\end{array}$ & $\begin{array}{c}0,06 \\
\text { Sangat } \\
\text { rendah } \\
(\text { Very } \\
\text { low) }\end{array}$ & 23,21 & 19,25 & $\begin{array}{c}>100 \\
\text { Sangat } \\
\text { tinggi } \\
\text { (Very } \\
\text { high) }\end{array}$ \\
\hline $\begin{array}{l}\text { Campuran } \\
\text { (Mixed } \\
\text { species)/B }\end{array}$ & $\begin{array}{c}\text { 1,8Sangat } \\
\text { rendah } \\
\text { (Very } \\
\text { low) }\end{array}$ & $\begin{array}{l}18,28 \\
\text { Tinggi } \\
(\text { High })\end{array}$ & $\begin{array}{c}2,79 \\
\text { Tinggi } \\
(\text { High })\end{array}$ & $\begin{array}{c}0,15 \\
\text { Rendah } \\
(\text { Low })\end{array}$ & $\begin{array}{c}0,07 \\
\text { Sangat } \\
\text { rendah } \\
(\text { Very } \\
\text { low) }\end{array}$ & 21,29 & 20,24 & $\begin{array}{c}59 \\
\text { Sedang } \\
\text { (Moderate) }\end{array}$ \\
\hline
\end{tabular}




\section{Analisa kesesuaian lahan}

Kelas kesesuaian lahan untuk sembilan jenis pada tapak A. mangium, yaitu untuk jati dan mahoni termasuk ke dalam kategori sesuai marginal dengan faktor pembatas drainase, kedalaman tanah, $\mathrm{pH}$, dan lereng (S3d,s,pH dan lereng); nangka termasuk ke dalam kategori tidak sesuai $(\mathrm{N})$; rambutan dan pinang termasuk ke dalam kategori sesuai marginal dengan faktor pembatas kedalaman tanah dan lereng $\left(\mathbf{S}_{3 t}\right.$ dan 1); pisang termasuk ke dalam kategori sesuai marginal dengan faktor pembatas curah hujan, kedalaman tanah, dan lereng (S3ch,t, dan I); jagung dan cabe termasuk ke dalam kategori sesuai marginal dengan faktor pembatas curah hujan dan lereng (S3ch dan 1); dan rumput gajah termasuk ke dalam kategori sesuai marginal dengan faktor pembatas curah hujan (S3ch). Kelas kesesuaian lahan untuk sembilan jenis di atas pada tapak tanaman campuran, masing-masing untuk jati dan mahoni termasuk ke dalam kategori sesuai marginal dengan faktor pembatas drainase, kedalaman tanah dan lereng (S3d,t, dan 1); nangka termasuk ke dalam kategori tidak sesuai $(\mathrm{N})$; rambutan dan pinang termasuk ke dalam kategori sesuai marginal dengan faktor pembatas lereng, kedalaman tanah dan curah hujan (S3ch, l, dan t); pisang dan jagung termasuk ke dalam kategori sesuai marginal dengan faktor pembatas curah hujan dan lereng (S3ch dan 1); cabe termasuk ke dalam kategori sesuai marginal dengan faktor pembatas curah hujan dan lereng (S3ch dan 1); rumput gajah termasuk ke dalam kategori sesuai marginal dengan faktor pembatas curah hujan $\left(\mathbf{S}_{3} \mathbf{c h}\right)$, seperti disajikan pada Tabel 4. Sementara itu, kesesuaian lahan potensial dan kombinasi jenis dapat dilihat pada Lampiran 1.

Tabel (Table) 4. Penilaian kelas kesesuaian untuk masing-masing karakteristik lahanper jenis di tapak A. Mangium (AM) dan tanaman campuran (TC) (Land suitability classes assessment on each land characteristics and species at AM and TCsites) ${ }^{*}$

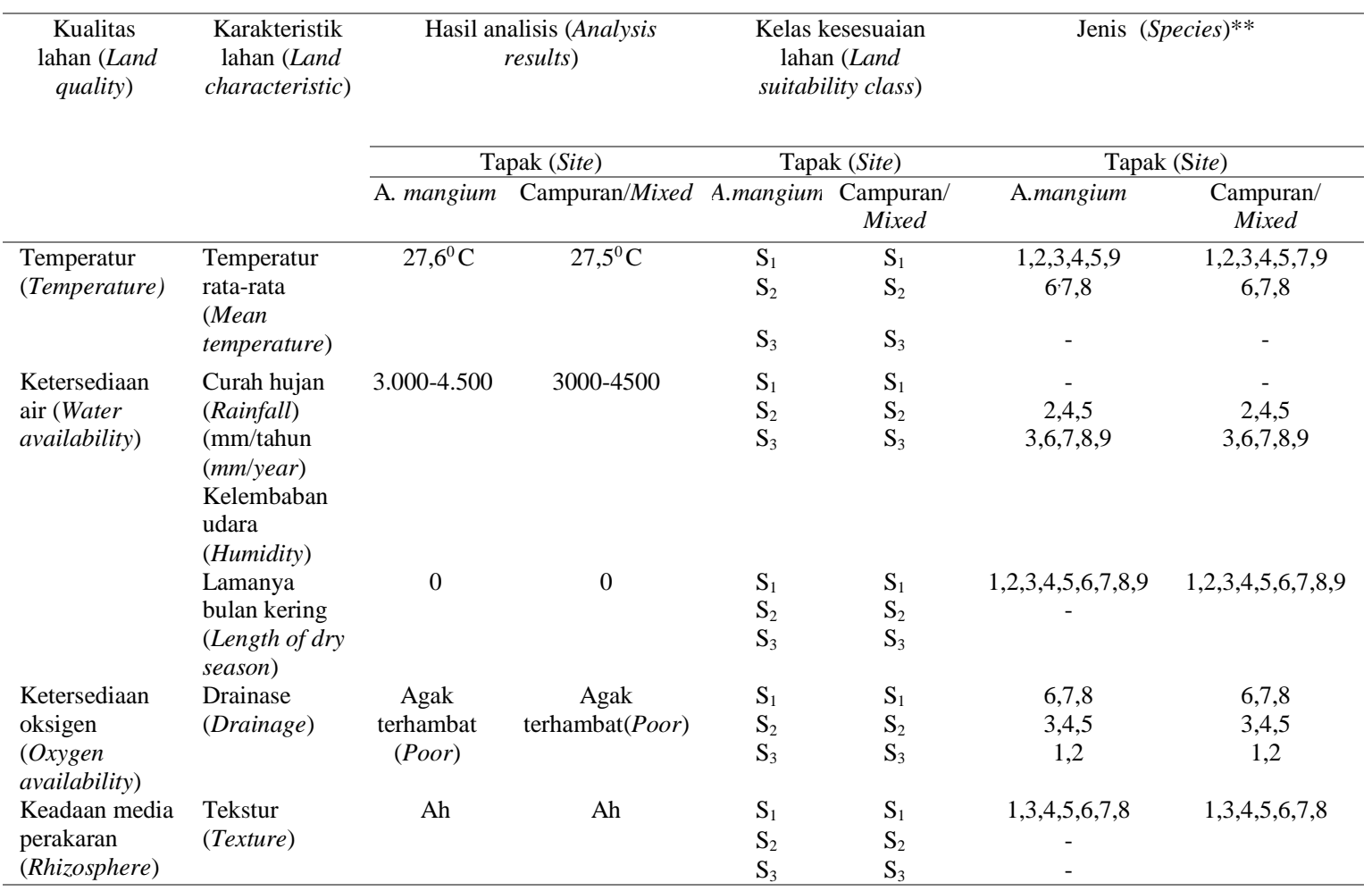


Tigor Butarbutar, Ismatul Hakim, Niken Sakuntaladewi, Hariatno Dwiprabowo, Lukas Rumboko dan Setiasih Irawanti

Tabel (Table) 4. Lanjutan (continued)

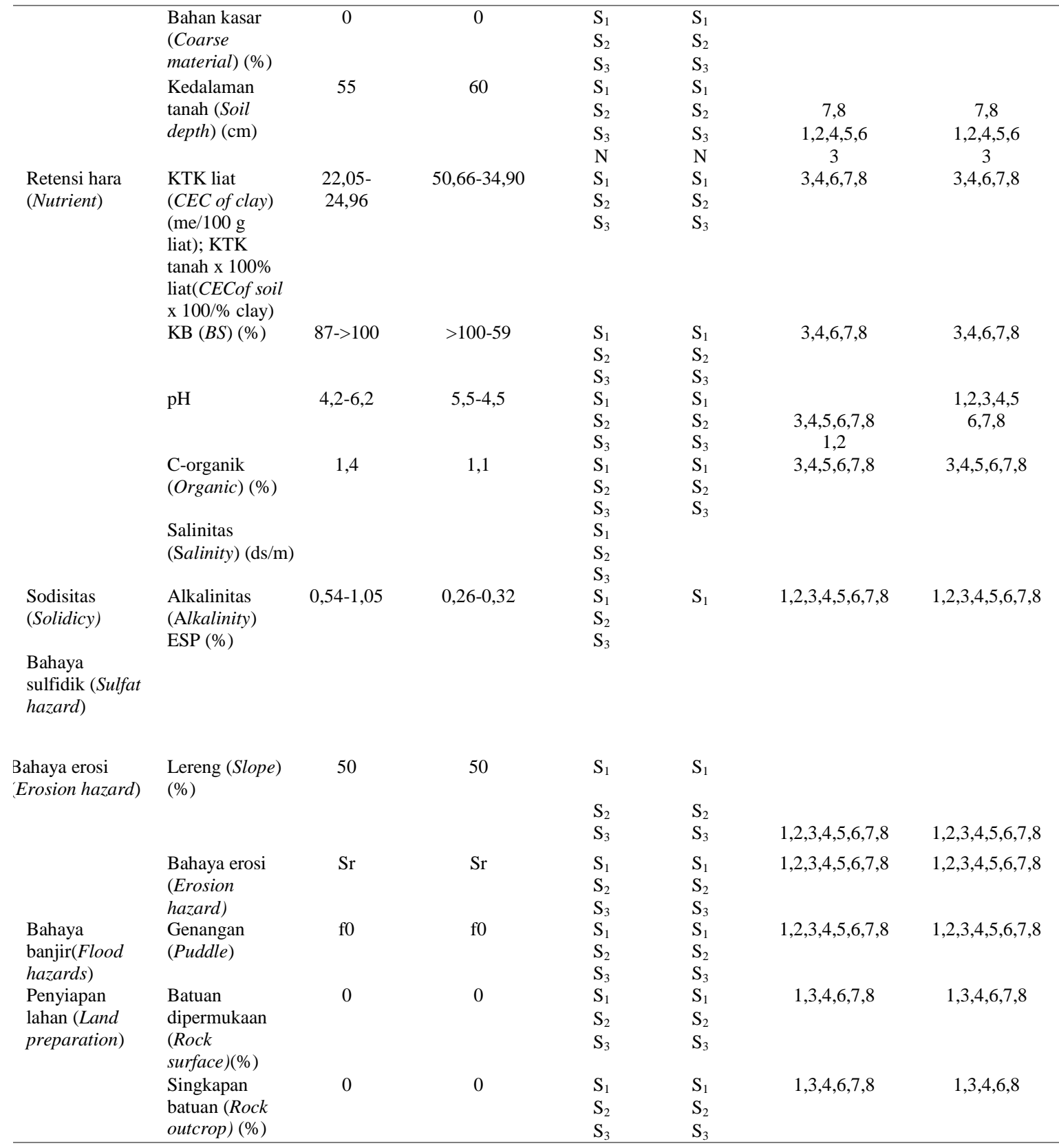

Keterangan (Remarks) : *= Berdasarkan (Based on)Djaenudin,Marwan, Subagyo, \& Hidayat. (2003);**= Brack (1928): $26,3^{\circ} \mathrm{C}-\left(0,01^{*}\right.$ elevasi $\left.* 0,6^{\circ} \mathrm{C}\right) ; 1=$ jati $(T$. grandis $) ; 2=$ mahoni $(S$. macrophylla $) ; 3=\operatorname{nangka}(A$. integra $) ; 4=\operatorname{rambutan}(N$. lappaceum $) ; 5=\operatorname{pinang}(A$. catechu); 6= pisang (Musa sp.); 7= jagung (Z. mays); 8= cabe (Capsicum sp.), dan $9=$ rumput gajah $(P$. purpureum $)$

\section{B. Pembahasan}

Hasil deskripsi profil tanah (Tabel 1), analisa sifat fisik dan kimia tanah (Tabel 2 dan 3) di kedua lokasi penelitian menunjukkan tanah termasuk sulit untuk diolah, tidak subur baik secara fisik maupun kimiawi. Disamping itu, hasil penilaian kesesuian lahan aktual di lokasi penelitian (Tabel 4) menunjukkan bahwa kemiringan lereng dan curah hujan merupakan faktor pembatas minimum alami dan sulit dirubah. Usaha untuk meningkatkan kesesuaian lahan menjadi lebih tinggi setingkat pada kedua tapak dapat dilakukan rehabilitasi kesuburan 
fisik dan kimianya, tetapi dibutuhkan biaya yang relatif mahal. Rehabilitsi kesuburan sifat fisik dilakukan dengan penerapan teknik konservasi tanah dan air (baik secara mekanis maupun vegetatif), sedangkan secara kimia dengan pengapuran untuk menurunkan kemasam-an tanah, penambahan bahan organik untuk meningkatkan kandungan nitrogen atau menambahkan pupuk NPK. Walangitan (2014) mengemukakan bahwa teknik konservasi tanah berbasis tanaman cengkeh pernah dilakukan pada sebagian daerah tangkapan Danau Tondano sehingga lahan tersebut dapat dimanfaatkan untuk agroforestri. Sementara itu, Boitt, Mundia, Pellikka, \& Kapoi (2015) menyebutkan bahwa faktor pembatas alami kesesuaian lahan di pegunungan Taiti, Kenya, antara lain curah hujan dan temperatur, yang mana di wilayah temperatur tinggi dan curah hujan rendah termasuk paling tidak sesuai (least suitable). Demikian pula dengan Grant, Moffatt, Sethy, Grieve, \& Convery (2012) yang menyebutkan bahwa salah satu karakteristik lahan yang sesuai untuk lokasi pengembangan pohon Endospermum mendullosum di Espiritu Santo, Vanuatu, adalah lahan yang mempunyai kemiringan ringan (gentle slope).

Untuk mengembangkan pola tanaman di kondisi lahan yang sulit diolah dan tidak subur baik secara fisik dan mekanis dibutuhkan kombinasi jenis yang sangat terbatas yaitu alternatif campuran masing-masing 1 jenis tanaman kayu, 1 jenis tanaman MPts, 1 jenis tanaman pangan atau pakan ternak dan jenis tanaman rumput, mengingat kesesuaian lahan untuk semua jenis termasuk ke dalam kategori marjinal (agak sesuai) dengan faktor pembatas kemiringan lahan (kecuali untuk jenis A. Integra) pada tapak A. mangium, sedangkan di tapak tanaman campuran termasuk ke dalam kategori tidak sesuai.

Pembangunan agroforestri pada kondisi lahan seperti ini perlu dilakukan dengan mengembangkan pola campuran yang sangat terbatas. Hal ini disebabkan oleh tanah dengan sifat-sifat yang sulit diolah karena bertekstur dan berstruktur berat, tanah termasuk masam sampai sangat masam, bahan organik termasuk rendah sampai sangat rendah, dan Ptersedia sangat rendah. Jenis palawija yang memungkinkan untuk ditanam pada tahap awal untuk agroforestri adalah jagung atau cabe. Hasil analisis kesesuaian lahan menunjukkan bahwa karakteristik lahan seperti temperatur masih menunjukkan kelas $\mathrm{S}_{2}$ (agak sesuai), sedangkan jumlah bulan kering, drainase, kedalaman tanah, bahan organik, KTK, KB, bahaya erosi, bahaya genangan, batuan di permukaan dan singkapan batuan termasuk $\mathrm{S}_{1}$ (sesuai). Setelah tanaman palawija dapat dilanjutkan dengan tanaman rumput gajah di bawah tegakan yang relatif tahan naungan seperti A. mangium yang sudah tumbuh baik di lokasi penelitian. Jenis pohon mahoni dan jati tidak akan dapat optimal, jadi perlu dicoba jenis seperi Pinus merkusii yang relatif toleran terhadap tanah masam. Penamaman MPTs seperti jenis-jenis pinang, nangka dan rambutan tidak akan berproduksi maksimal, perlu dicoba dengan tanaman MPTs yang relatif tahan terhadap tanah masam, bertekstur dan struktur tanah berat seperti pisang masih memungkinkan.

Akiefnawati \& Rahayu (2016) juga menyebutkan bahwa pembangunan agroforestri di Jambi dilakukan dengan pola tanam yang disesuaikan dengan kemiringan lahan. Urutan penanaman tersebut mulai dari bagian puncak lereng yang ditanam dengan jenis tanaman kayu yang diikuti tanaman MPTs dari jenis karet, kemudian jenis tanaman MPTs lain (kayu manis), dan terakhir pada lereng terbawah yang ditanami jenis rempah dan tanaman obat. Jarak tanam untuk jenis penghasil kayu adalah $5 \times 5 \mathrm{~m}$, karet 2,5 x 2,5 m, kayu manis $3 \times 3 \mathrm{~m}$, dan 
Tigor Butarbutar, Ismatul Hakim, Niken Sakuntaladewi, Hariatno Dwiprabowo, Lukas Rumboko dan Setiasih Irawanti

tanaman rempah atau tanaman obat $30 \mathrm{x}$ $30 \mathrm{~cm}$. Selain itu, pertimbangan pemilihan jenis pohon menjadi penting jika dicampur dengan tanaman sela karena distribusi cahaya melalui kanopi dapat menjadi faktor pembatas pada tanaman sela dibawah kanopi. Leroy et al. (2009) menyebutkan bahwa cahaya yang sampai ke tanaman sela tergantung jumlah cahaya yang terintersepsi melalui kanopi sebagai akibat struktur/arsitektur kombinasi campuran pohon. Sebagai contoh, campuran A. mangium dan $\mathrm{T}$. grandis pada umur 1 dan 3 tahun, akan memperterlihatkan bahwa penutupan kanopi A. mangium pada umur 3 tahun lebih cepat, sehingga cahaya yang didapatkan tanaman sela di bawah A. mangium tiga kali lebih rendah dibandingkan dengan tanaman dibawah T. grandis (Leroy et al., 2009). Pemilihan kombinasi tanaman juga disebutkan oleh Markum et al. (2013) yang mana pola agroforestri dengan campuran pohon jati dan mahoni, serta MPTs (durian, alpukat, mangga, coklat dan kopi) di DAS Renggung Pulau Lombok dapat meningkatkan pendapatan petani yang dilibatkan dengan skema hutan kemasyarakatan (HKm).

\section{KESIMPULAN DAN SARAN}

\section{A. Kesimpulan}

Kesesuaian lahan pada kawasan hutan di Desa Nambo untuk jenis jati (T. grandis), mahoni (S. macrophylla), rambutan (N. lappaceum), pinang (A. catechu), pisang (Musa sp.), jagung (Z. mays), cabe (Capsicum sp.), dan rumput gajah (P. purpureum) termasuk ke dalam kategori sesuai marginal $\left(\mathbf{S}_{3}\right)$, baik pada tapak A. mangium maupun tanaman campuran. Sebaliknya, kesesuaian lahan untuk jenis A. integra (nangka) termasuk ke dalam kategori tidak sesuai (N) dengan faktor pembatas alami yang sulit dirubah, seperti kemiringan lahan dan curah hujan. Sementara itu, kombinasi jenis yang dapat dilakukan sangat terbatas dengan alternatif campuran masing-masing 1 jenis tanaman kayu, 1 jenis tanaman MPTs, 1 jenis tanaman pangan atau pakan ternak.

\section{B. Saran}

Pengembangan agroforestri pada tapak A. mangium dan tanaman campuran yang termasuk ke dalam kategori sesuai marginal dan kombinasi jenis yang sangat terbatas perlu diawali dengan skala uji coba dengan jenis-jenis yang dikembangkannya.

\section{UCAPAN TERIMAKASIH}

Penulis mengucapkan terima kasih kepada Balai Pengelolaan Sampah Regional Jawa Barat yang telah membiayai penelitian ini dan Bapak Edi Bahtiar yang telah membantu pelaksanaan penelitian.

\section{DAFTAR PUSTAKA}

Ahmad, F., \& Goparaju, L. (2017). Land evaluation in terms of agroforestri suitability, an approach to improve livelihood and reduce poverty: A FAO based methodology by geospatial solution: A case study of Palamu district, Jharkhand, India. Ecological Questions,25, 67-84. http://dx.doi.org/10.12775/EQ.2017. 006.

Ahmad, F., Goparaju, L., \& Qayum, A. (2017). Agroforestri suitable analysis based upon nutrient availability mapping: A GIS based suitability mapping. AIMS Agriculture and Food, 2(2), 201-220.

Akiefnawati, S., \& Rahayu, S. (2016). Pedoman agroforestri dalam pengelolaan Hutan Desa: pembelajaran dari Jambi. Bogor: Agroforestri Centre (ICRAF) 
Southeast Asia Regional Program.

Asmarhansyah, A., Badayos, R.B., Sanchez, P.B., Cruz, P.C.S., \& Florece, L.M. (2017). Land suitability evaluation of abandoned tin-mining areas for agricultural development in Bangka Island, Indonesia. Journal of Degraded Mining Land, 4(4). https://doi.org/10.15243/jdmlm.2017 .044.907.

Boitt, M.K., Mundia, C.N., Pellikka, P.K.E., \& Kapoi, J.K. (2015). Land suitability assessment for effective crop production, a case study of Taiti Hills, Kenya. Journal of Agricultural Informatics, 6(2), 23-31. http://doi.org/10.17700/jai.2015.6.2. 185.

Butarbutar, T. (2015). Reinforcing agroforestri to meet the need for timber, fruits and food into HTR scheme-based on land suitability and necessary policy: A case study in Riau. Proceedings International Conference of Indonesia Forestry Researchers III, Bogor21-22 October 2015. Bogor: Forestry Research, Development and Innovation Agency, 158-169.

Fiqa, A.P., \& Laksono, R.A. (2014). Pengembangan sistem agroforestri berbasis indigenous species dan kesesuaian lahan di wilayah Kabupaten Pasuruan, Jawa Timur. Makalah disajikan dalam Seminar Nasional Agroforestri, Malang: Lembaga Ilmu Pengetahuan Indonesia.

Grant, J.C., Moffatt, T., Sethy, M., Grieve, B., \& Convery, K. (2012). Site suitability and land availability for Endospermum medullosum plantation on Espiritu Santo, Vanuatu. International Forestry Review, 14(4), 424-432.

Leite, L.F.C., Iwata, B.F., \& Araujo,
A.S.F. (2014). Soil organic matter pools in a tropical savanna under agroforestri system in Northeastern Brazil. Revista Arvore, Vicosa-M.G, 38(4), 711-723. Retrieved from http://dx.doi.org/10.1590/S010067622014000400014.

Leroy, C., Sabatir, S., Wahyuni, N.S., Barczi, J.F., Dauzat, J., Laurans, M., \& Auclair, D. (2009). Virtual trees and light capture: A method for optimizing agroforestry stand design. Agroforestri System, 77(1), 37-47.

Markum, A.P., Hadi, Suyono, \& Muktar. (2013). Kesesuaian karakteristik agroforestri untuk pengelolaan DAS terpadu di DAS Renggung Pulau Lombok In Utomo (Eds.), Prosiding Seminar Nasional Pengelolaan DAS terpadu untuk Kesejahteraan Masyarakat, 150-162.

Rachmawaty, R., Siregar, N.C., \& Rauf, A. (2016). Kesesuaian lahan tanaman jati: Studi kasus di Arboretum Kwala Bekala, Universitas Sumatera Utara. Jurnal Penelitian Dipterokarpa, 2(2), 73-82.

Rahim, S.M.A., Hasnain, S., \& Shamsi, R.A. (2010). Land suitability classification of choice of tree species in District Rahim Yar Khan, Punjab, Pakistan. African Journal of Agricultural Research, 5(23), 32193229.

http:www.academicjournals.org/AJA R.

Ritung, S., Wahyuanto., Agus, F., \& Hidayat, H. (2007). Panduan evaluasi kesesuain lahan dengan contoh peta arahan penggunaan lahan Kabupaten Aceh Barat. Balai Penelitian Tanah dan Agroforestri Centre (ICRAF), Bogor. Indonesia.

Walangitan, H.D. (2014). Perencanaan rehabilitasi hutan dan lahan (RHL) berbasis kemampuan lahan di daerah tangkapan air (DTA) Danau 
Tigor Butarbutar, Ismatul Hakim, Niken Sakuntaladewi, Hariatno Dwiprabowo, Lukas Rumboko dan Setiasih Irawanti

Tondano. Jurnal Wasian, 1(2), 45-56.

Wang, L., Zhong, C., Gao, P., Xi, W., \& Zhang, S. (2015). Soil infiltration characteristics in agroforestri system and their relationship with the temporal distribution of rainfall on the loess plateu in China. PLoSone, 10(4). Retrieved 7 September 2017 from

https://doi.org/10.1371/journal.pone. 0124767.

Wicaksono, H., Putra, E.T.S., \& Muhartini, S. (2015). Kesesuaian tanaman ganyong (Canna indica L.), suweg

(Amorphophallus paeoniifolius (Dennst.) Nicolson), dan ubi kayu (Manihot esculenta Crantz) pada agroforestri Perbukitan Menoreh. Vegetalika, 4(1).

Winarno, J., Rachmadhika, Y., \& Supriyadi. (2010). Evaluasi kesesuaian "beberapa jenis tanaman dalam sistem wanatani di wilayah Desa Ngadipuro, Kecamatan Nguntoronadi, Kabupaten Wonogiri. Sains Tanah-Jurnal Ilmu Tanah dan Agroklimatologi, 7(2), 97-107. 
Lampiran (Appendix) 1. Kesesuaian lahan aktual dan potensial per jenis dan alternatif kombinasi campuran (Actual and potential land suitability for each species and alternative for mixed combination)

\begin{tabular}{|c|c|c|c|c|c|c|c|c|}
\hline \multirow{4}{*}{$\begin{array}{c}\text { Jenis } \\
\text { (Species) }\end{array}$} & \multicolumn{4}{|c|}{ Kesesuaian lahan (Land suitability) } & \multirow{2}{*}{\multicolumn{2}{|c|}{$\begin{array}{l}\text { Faktor pembatas } \\
\text { (Limitation factor) }\end{array}$}} & \multirow{2}{*}{\multicolumn{2}{|c|}{$\begin{array}{l}\text { Kombinasi campuan } \\
\text { (Mixed combination) }\end{array}$}} \\
\hline & \multirow{2}{*}{\multicolumn{2}{|c|}{$\begin{array}{c}\text { Aktual }(\text { Actual)* } \\
\text { Tapak }(\text { Site })\end{array}$}} & \multirow{2}{*}{\multicolumn{2}{|c|}{$\begin{array}{c}\text { Potensial (Potential) } \\
\text { Tapak (Site) }\end{array}$}} & & & & \\
\hline & & & & & Tapak & (Site) & & pak (Site) \\
\hline & $\begin{array}{c}\text { A. } \\
\text { mangium }\end{array}$ & $\begin{array}{l}\text { Campuran } \\
\text { (Mixed) }\end{array}$ & $\begin{array}{c}\text { A. } \\
\text { mangium }\end{array}$ & $\begin{array}{c}\text { Campuran } \\
\text { (Mixed) }\end{array}$ & A. mangium & $\begin{array}{l}\text { Campuran } \\
\text { (Mixed) }\end{array}$ & $\begin{array}{c}\text { A. } \\
\text { mangium }\end{array}$ & $\begin{array}{l}\text { Campuran } \\
\text { (Mixed) }\end{array}$ \\
\hline 1.Jati & $\mathrm{S}_{3}$ & $\mathrm{~S}_{3}$ & - & - & $\begin{array}{l}\text { Lereng } \\
\text { (Slope), } \\
\text { curah } \\
\text { hujan } \\
\text { (rianfall) }\end{array}$ & $\begin{array}{l}\text { Lereng } \\
\text { (Slope), } \\
\text { curah } \\
\text { hujan } \\
\text { (rainfall) }\end{array}$ & & $\begin{array}{l}1+ \\
(2 / 4 / 5 / 6 / 7 / 8)+9\end{array}$ \\
\hline 2.Mahoni & $\mathrm{S}_{3}$ & $\mathrm{~S}_{3}$ & - & - & $\begin{array}{l}\text { Lereng } \\
\text { (Slope) }\end{array}$ & $\begin{array}{l}\text { Lereng } \\
\text { (Slope) }\end{array}$ & & $\begin{array}{l}2+ \\
(4 / 5 / 6 / 7 / 8)+9\end{array}$ \\
\hline 3.Nangka & $\mathrm{N}$ & $\mathrm{N}$ & - & - & $\begin{array}{l}\text { Lereng } \\
\text { (Slope) }\end{array}$ & $\begin{array}{l}\text { Lereng } \\
(\text { Slope })\end{array}$ & & \\
\hline 4. Rambutan & $\mathrm{S}_{3}$ & $\mathrm{~S}_{3}$ & - & - & $\begin{array}{l}\text { Lereng } \\
\text { (Slope) }\end{array}$ & $\begin{array}{l}\text { Lereng } \\
\text { (Slope) }\end{array}$ & & $\begin{array}{l}4+ \\
(2 / 5 / 6 / 7 / 8)+9\end{array}$ \\
\hline 5.Pinang & $\mathrm{S}_{3}$ & $\mathrm{~S}_{3}$ & - & - & $\begin{array}{l}\text { Lereng } \\
\text { (Slope) }\end{array}$ & $\begin{array}{l}\text { Lereng } \\
\text { (Slope) }\end{array}$ & & $\begin{array}{l}5+ \\
(2 / 4 / 6 / 7 / 8)+9\end{array}$ \\
\hline 6.Pisang & $\mathrm{S}_{3}$ & $\mathrm{~S}_{3}$ & - & - & $\begin{array}{l}\text { Lereng } \\
\text { (Slope) }\end{array}$ & $\begin{array}{l}\text { Lereng } \\
\text { (Slope) }\end{array}$ & & $\begin{array}{l}6+ \\
(2 / 4 / 5 / 7 / 8)+9\end{array}$ \\
\hline 7.Jagung & $\mathrm{S}_{3}$ & $\mathrm{~S}_{3}$ & - & - & $\begin{array}{l}\text { Lereng } \\
\text { (Slope) }\end{array}$ & $\begin{array}{l}\text { Lereng } \\
\text { (Slope) }\end{array}$ & & $\begin{array}{l}7+ \\
(2 / 4 / 5 / 6 / 8)+9\end{array}$ \\
\hline $\begin{array}{l}\text { 8.Cabe } \\
\text { merah }\end{array}$ & $\mathrm{S}_{3}$ & $\mathrm{~S}_{3}$ & - & - & $\begin{array}{l}\text { Lereng } \\
\text { (Slope) }\end{array}$ & $\begin{array}{l}\text { Lereng } \\
\text { (Slope) }\end{array}$ & & $\begin{array}{l}8+ \\
(2 / 4 / 5 / 6 / 7 / 8)+9\end{array}$ \\
\hline $\begin{array}{l}\text { 9. Rumput } \\
\text { gajah }\end{array}$ & $\mathrm{S}_{3}$ & $\mathrm{~S}_{3}$ & - & - & $\begin{array}{l}\text { Lereng } \\
\text { (Slope) }\end{array}$ & $\begin{array}{l}\text { Lereng } \\
\text { (Slope) }\end{array}$ & & $(2 / 4 / 5 / 6 / 7)$ \\
\hline
\end{tabular}

Keterangan (Remarks): * = Sesuai hasil analisis kesesuaian lahan di Tabel 4 (Based on land suitability on Table 4) 